\title{
Implications of Priority Use of the Village Fund Year 2021 in Delivering Village without Poverty in East Lampung District
}

\author{
Agung Budi Prastyo \\ Law Faculty \\ Lampung University \\ Lampung, Indonesia \\ agung.prastyo@fh.unila.ac.id
}

\author{
Satria Prayoga \\ Law Faculty \\ Lampung University \\ Lampung, Indonesia \\ satria.prayoga@fh.unila.ac.id
}

\begin{abstract}
Village without poverty is one of the main of the 17 main objectives of sustainable development Goals in Indonesia, the government's commitment in achieving the objectives and considers it important that agenda with the release PP Number 59 of 2017 concerning the Implementation of Achieving the Sustainable Development Goals. Strong communication and cooperation between stakeholders from the central, regional to village levels are important in making it happen. The village as the smallest government entity has an important role in realizing this agenda, after the issuance of Law Number 6 of 2014 it restores the existence of the village as an independent subject through the principle of recognition and the principle of subsidiarity as well as adequate sources of funds, so that the village has an important role in accelerating the realization of sustainable development goals. , in the implementation of village development, it has a reference in the form of priority for the use of village funds, in $\mathbf{2 0 2 1}$ this priority is regulated by Permendes Number 13 of 2020 Based on the description above, this study aims to find out how the process of determining the priority for the use of village funds and its implications in realizing a village without poverty as one of the objectives. sustainable development in East Lampung Regency. The contribution of this research can be an input for the Village Government in East Lampung Regency in determining policies in determining priorities for the use of village funds in achieving sustainable development goals, especially the achievement of villages without poverty so that the realization of an increase in the village economy and human resources and equal distribution of benefits from the use of village funds in East Lampung Regency.
\end{abstract}

Keywords-Village, Village Fund, Poverty, SDGs, East Lampung

\section{INTRODUCTION}

Sustainable development has been introduced since the 1972 Stockholm Conference on the Environment.
However, it will take a long time for the concepts and methods of sustainable development to be accepted by non-environmental stakeholders. With the introduction of the Sustainable Development Goals Declarations (SDGs) in 2015, people in all countries have begun to recognize the importance of implementing sustainable development. [1].

The Government of Indonesia's commitment to seeing the importance of sustainable development and implementing it towards the determination and achievement of the SDGs is contained in Presidential Regulation No. 59 of 2017 [2]. In this regulation, it is formulated that the objectives of the SDGs are to maintain the sustainable improvement of the community's economic welfare, maintain the sustainability of the social life of the community, and maintain environmental quality. life and inclusive development and implementation of governance that can maintain the improvement of the quality of life from one generation to the next.

The importance of these regulations is to ensure the implementation of the achievement of the Sustainable Development Goals. Guaranteed achievement is implemented through strengthening communication, socialization, and advocacy as well as strengthening cooperation with stakeholders. Thus, there will be an alignment of the development process at all levels, namely the central government, provincial and district/city governments, as well as villages. In the context of village governance, the question that arises is whether the goals and 17 SDGs agendas can be aligned with the priorities for using village funds.

Law No. 6 of 2014 concerning Villages to restore the existence of the village as an independent subject through the principle of recognition and the principle of subsidiarity [3]. Based on this principle, local-scale affairs are decided locally with the authority of the Village, and local problems are also resolved locally. 
Subsidiarity contains the spirit of respecting, trusting, and challenging the village to move. Thus, the village has strong institutions and the ability to develop regulations at the local village level following their authority. This paradigm shift was followed by the allocation of village funds as regulated in Government Regulation no. 43 of 2014 concerning Implementing Regulations of Law Number 6 of 2014 concerning Villages, which has twice been amended with the issuance of Government Circular No. 60 of 2014 and Government Regulation 8 of 2018.

Number Changes after the issuance of Law Number 6 of 2014 concerning the village places the village in being able to participate in realizing the SDGs agenda which has become the commitment of the Indonesian government and local governments. Villages already have important prerequisites in implementing the Sustainable Development Goals (SDGs), namely the existence of a legal basis, strong institutions, and the necessary financial resources. These prerequisites relate to the burden of the village government authority's obligation to implement through public services according to village authority.

Village law is changing the government's paradigm of seeing villages from state-centric to social-centric [4]. The old paradigms were state-centric, dictatorial, top-down, centralized, hierarchical, sectoral, and so on. On the other hand, the new paradigm seems to incorporate a spirit of social-centered awareness and complementarity, such as democracy, bottom-up, autonomy, independence, regionality, participation, and liberation. Village law puts the spirit of village development within the framework of national development.

The position of the Village after the issuance of Law Number 6 of 2014 became very important. The strategic position and acceleration efforts could be placed within the framework of sustainable development (SDGs) which has become a global issue. As a party that plays an active role in determining the targets of the Sustainable Development Goals/SDGs, the Indonesian government has a high commitment to realizing the 17 criteria and targets to be achieved through the national mid-term development priorities. The 2015-2019 RPJMN was prepared in 2014, many of the SDGs targets are already included in the national development priorities. Of the 169 targets in the SDGs, about 57 percent (96 SDGs targets) have been following national development priorities

\section{DISCUSSION}

\section{A. Concepts and Goals of Sustainable Development}

Far, economic development (economic growth) has been the main focus and measure of achievement of development success in all countries. The impact on the environment has not been taken into account and is left to be the responsibility of the people who are victims, either directly to their lives, or indirectly because their economic activities are declining. Estimates of environmental impacts also need to be understood by every Indonesian and apply them not only in economic behavior but also in social behavior.

The concept of sustainable development makes the environment one of the pillars that become the focus and measure of implementation achievement, it means that the internalization of environmental impacts into economic and social activities, because internalizing environmental impacts on every economic activity carried out by the community is the only way to control the impact of each economic activity. on human health and environmental health. Internalization of the impact on the environment also needs to be carried out on social pillars, both in the fields of health, education in general, population, and housing.

Some of the differences between sustainable development and previous development methods [1]:

a) Macro: GDP, which so far has been an achievement to generate growth and monetary income for the welfare of people's lives, is no longer adequate because:

- It does not take into account the damage to nature that has reduced and even eliminated local people's access to nature for their life activities. Economic activities do not take into account the impact of pollution on the surrounding community, in other words, the impact of pollution that is detrimental to the community (diseases caused by pollution, damage to the younger generation affected by pollution), is not taken into account in "the method of production, the materials used and the value of the impact borne" in the way produce the goods. On a macro basis, the damage and decline in natural resources are often calculated in the form of depletion, which is not assessed. So far, it seems as if GDP continues to grow, but at the same time the depletion of natural resources is also large, and the impact of pollution on humans and the environment as well as biodiversity is also large. So, the value of this GDP should be reduced by the value of the social and environmental impacts;

- Does not take into account the value of "income" of the surrounding community which is not calculated in GDP, because they consume materials from nature (fruits and vegetables picked from gardens and forests; firewood from forests, animals caught, fish caught from rivers).

b) On a micro level: The production process which so far does not use efficient, clean technology and environmentally friendly materials, must change. Technology that is inefficient in the use of resources tends to waste the use of resources that should be able to: 
- Produce more output; or

- Can produce the output we need for a longer time;

- Produces output with less waste, resulting in minimal load and damage. Likewise, by using environmentally friendly materials, we can enjoy output without leaving destructive waste, or leaving a minimal amount of destructive waste, at a level that can be absorbed and reprocessed by nature, so that the environment can continue to function to support life.

More transformatively: Previous developments assume that the use of nature and the resources in it can be sustainable because there will be new technologies that help overcome limitations. Thus, even though the necessities of life are growing in line with the increase in population, nature and the resources in it are still used as if without limits. Sustainable development requires and requires a very different "point of view" because resources and nature have limits and become the limits of life in the world. That with the development of the human population and the use of nature and its contents, at this time it has reached a point where nature has a limit or known as a planetary boundary.

\section{B. Priority for Use of Village Funds in 2021}

The use of Village Funds in 2021 is regulated in Regulation of the Minister of Villages, Development of Underdeveloped Regions and Transmigration number 13 of 2020, wherein the regulation the priority of using Village Funds in 2021 is still directed at social safety nets, Safe Villages COVID -19 and national economic recovery that includes national strategic sectors. The national strategic sector in question includes the following:

- Energy facilities/infrastructure;

- Communication facilities/infrastructure;

- Tourism facilities/infrastructure;

- Prevention of stunting; and

- Inclusive village development.

The objectives of the priority use of village funds in 2021 are as follows:

- Provide directions for the use of village funds in 2021 for national economic recovery, national priority programs, and adaptation of new habits to support the achievement of Village SDGs

- Set the Priority for Use of Village Funds, Determination of Priority for Use of Village Funds, publication and reporting, as well as guidance, monitoring, and evaluation of Priority Use of Village Funds.

Furthermore, the Priority for the Use of Village Funds in 2021 is based on several principles, namely:
- Humanity is prioritizing basic rights, human dignity, and worth;

- Justice is prioritizing the fulfillment of the rights and interests of all Village residents without discriminating;

- Diversity is the recognition and respect for cultural diversity and local wisdom as a form of social piety based on universal human values;

- Natural balance is prioritizing sustainable earth care for the sustainability of human life; and

- National interest is prioritizing the implementation of national strategic policies to realize people's welfare.

\section{Village SDGS Program}

The law places villages as subjects of development. With the spirit of a developing village that places the village as a subject that can plan, implement and oversee the course of development. The concept of developing a village is related to independence, local wisdom, social capital, democracy, participation, authority, allocation of funds, local movement, empowerment, etc. This concept places a village institutional scheme to establish regulations following village-scale authorities, institutionalize village planning, fund allocation, and local control. The goal is to be able to make the village the basis of livelihood and community life in a sustainable manner and as a front end that is close to the community, as well as an independent village.

The purpose of village development in the sense of village law is to meet the basic needs, develop village facilities and infrastructure, and develop the economic potential of the region, thereby the well-being and quality of life of the village community. Is to improve and fight poverty. Use natural resources and the environment sustainably. Sustainability means the development of villages to meet current needs without compromising the needs of future generations of villages.

To operationalize the Village development goals mandated by the Village Law, the use of the Village Fund is prioritized to realize 8 (eight) Village typologies and 18 (eighteen) Village SDGs goals as follows:

- Villages without poverty and hunger SDGs Village 1: Villages without poverty; and SDGs Village 2: Village without hunger.

- Village economy grows evenly

SDGs Village 8: Village economic growth is evenly distributed;

SDGs Desa 9: Village infrastructure and innovation as needed;

SDGs Desa 10: villages without inequality; and 
SDGs Desa 12: consumption and production Villages are environmentally conscious.

- Villages care about the health

SDGs Village 3: Healthy and prosperous villages;

SDGs Desa 6: Villages with clean water and sanitation; and

SDGs Desa 11: Village settlement areas are safe and comfortable.

- Village cares for the environment

SDGs Village 7: Clean and renewable energy village;

SDGs Desa 13: Climate change responsive villages;

SDGs Desa 14: Villages care about the marine environment; and

SDGs Desa 15: Villages care about the terrestrial environment.

- Villages care about education

SDGs Village 4: Quality village education.

- Villages are female-friendly

SDGs Desa5: involvement of Village women.

- Villages networked with

SDGs Desa 17: partnerships for village development.

- Villages that are culturally responsive to

SDGs Desa 16: Villages of peace and justice; and

SDGs Desa 18: dynamic village institutions and adaptive village culture.

Efforts to achieve village SDGs in COVID 19 pandemic situations and situations are not easy, so the use of Village Fund 2021 will be prioritized to fund activities aimed at achieving 10 village SDG support. Relationship with national economic recovery activities; national priority programs; and adaptation to new village customs. The 10 SGDs in the village are:

- Village without poverty;

- Village without hunger;

- Healthy and prosperous village;

- Village women's involvement;

- Clean and renewable energy village;

- Village economic growth is evenly distributed;

- Environmentally conscious village consumption and production;

- Village of peace and justice;

- Partnership for village development; and

- Dynamic village institutions and adaptive village culture.

Based on the previous description Poverty is still a top priority in achieving sustainable development goals, especially during the Covid 19 pandemic, deeper pressure is felt in improving people's welfare, according to the Minister of Village Regulation number 13 of 2020 and the 2030 village target, priority use of villages in 2021 [5]. We can see the SDGs Village program in 2021 in the following table.

TABLE I.

EXAMPLES OF IMPLEMENTING SDGs IN DESA 1 Village Without PoverTy

\begin{tabular}{|c|c|c|c|c|}
\hline No & Village Target in 2030 & Measuring & Indicators & Example Of Activities \\
\hline 1 & The poverty rate reaches $0 \%$ & $\begin{array}{l}\text { Village poverty rate } \\
\text { Percentage of population below } \\
\text { the rural poverty line } \\
\text { Percentage of families who own } \\
\text { family assets }\end{array}$ & $\begin{array}{l}\text { house condition } \\
\text { Shopping below the } \\
\text { poverty line } \\
\text { Total family income in the } \\
\text { last month }\end{array}$ & $\begin{array}{l}\text { Village cash labor- } \\
\text { intensive } \\
\text { Increasing job } \\
\text { opportunities in the } \\
\text { Bumdes business unit } \\
\text { Increase in Bumdes } \\
\text { capital for }\end{array}$ \\
\hline 2 & $\begin{array}{l}\text { Percentage of the population } \\
\text { participating in health insurance } \\
\text { through the Health Sector SJSN } \\
\text { reaches } 100 \%\end{array}$ & $\begin{array}{l}\text { Percentage of SJSN participants } \\
\text { in the village }\end{array}$ & $\begin{array}{l}\text { BPJS membership or } \\
\text { health card }\end{array}$ & $\begin{array}{l}\text { Proposed Health } \\
\text { Insurance Card for rural } \\
\text { communities in need }\end{array}$ \\
\hline 3 & $\begin{array}{l}\text { Poor families who are entitled to } \\
\text { conditional cash transfers } \\
\text { increase from year to year to } \\
100 \%\end{array}$ & $\begin{array}{l}\text { Change in the percentage of very } \\
\text { poor families receiving } \\
\text { conditional cash transfers from } \\
\text { year to year }\end{array}$ & $\begin{array}{l}\text { Belonging to a poor family } \\
\text { Social assistance recipient }\end{array}$ & $\begin{array}{l}\text { Data collection for poor } \\
\text { families } \\
\text { Provision of Village } \\
\text { Fund BLT } \\
\text { Proposal of Social } \\
\text { Assistance to Local } \\
\text { Government and Central } \\
\text { Government }\end{array}$ \\
\hline
\end{tabular}




\section{Implementation of Priority Use of Village Funds in 2021 in East Lampung Regency}

East Lampung Regency consists of 24 sub-districts and 264 villages, in 2021 the number of Village Funds to be distributed will not change with 2020 , which is Rp. 278,517,033,000, The use of Village Funds in 2021 refers to the Regulation of the Minister of Villages, Development of Underdeveloped Regions and Transmigration number 13 of 2020 concerning Priorities for Use of Village Funds in 2021, in addition to referring to the regulation, the priority of using village funds also adjusts to the current situation and conditions.

In 2020 until now the Covid 19 Pandemic has still not been overcome, the situation not only has an impact on the public health aspect but also suppresses the economic aspect, several measures have been taken to overcome this by the government, one of the efforts made is to adjust the use of the transfer budget to regional and village funds for the 2021 fiscal year through the Circular Letter of the Minister of Finance of the Republic of Indonesia Number SE-2/PK/2021, the adjustment to the use of the budget (Refocusing) will affect the priorities for the use of village funds in 2021, adjustments to the use of the village fund budget include:

- In the context of implementing the Implementation of Micro-Community Activity Restrictions (PPKM) in the village, the use of the Village Fund is determined, including:

a. Village Cash Assistance;

b. At least $8 \%$ (eight percent) of the Village Fund received by each village for activities to handle the COVID-19 pandemic which is the village authority, including for COVID-19 safe village actions and COVID-19 safe village task forces.

- The Governor/Regent/Mayor receiving the Village Fund encourages and monitors the implementation of activities to handle the COVID-19 pandemic funded from the Village Fund.

Based on the statement above, the impact of the COVID-19 pandemic and efforts to deal with it through budget refocusing, especially village funds on a priority scale, are the priority activities in 2021 , this also affects efforts to achieve the use of village funds, especially villages without poverty.

\section{CONCLUSION}

\section{A. Conclusion}

The commitment of the Government of Indonesia to view the importance of sustainable development and implement it towards the determination and achievement of the SDGs is contained in Presidential Regulation Number 59 of 2017. The importance of this regulation is the certainty of the implementation of the achievement of the Sustainable Development Goals. Guaranteed achievement is implemented through strengthening communication, socialization, and advocacy as well as strengthening cooperation with stakeholders.

So far, economic development (economic growth) has been the main focus and measure of achievement of development success in all countries. The impact on the environment has not been taken into account and is left to be the responsibility of the victimized community. The concept of sustainable development makes the environment one of the pillars that become the focus and measure of implementation achievement, it means that the internalization of environmental impacts into economic and social activities, because internalizing environmental impacts on every economic activity carried out by the community is the only way to control the impact of each economic activity. on human health and environmental health.

The use of the 2021 Village Fund is regulated in the Regulation of the Minister of Villages, Underdeveloped Regional Development and Transmigration number 13 of 2020, wherein the regulation the priority for the use of the 2021 Village Fund is still directed at social safety nets, COVID-19 Safe Villages and national economic recovery that covers national strategic sectors.

The objectives of the priority use of village funds in 2021 are as follows:

- Provide direction for the Priority of Use of Village Funds in 2021 for national economic recovery, national priority programs, and adaptation of new habits to support the achievement of the Village SDGs.

- Set the Priority for Use of Village Funds, Determination of Priority for Use of Village Funds, publication and reporting, as well as guidance, monitoring, and evaluation of Priority Use of Village Funds.

Efforts to achieve the Village SDGs in the COVID19 Pandemic situation and conditions are not easy, therefore, the use of the 2021 Village Fund is prioritized to finance activities that support the achievement of 10 (ten) Village SDGs related to national economic recovery activities; national priority programs; and adaptation of new village habits,

one of the efforts made is to adjust the use of the transfer budget to the regions and village funds for the 2021 fiscal year through the Circular Letter of the Minister of Finance of the Republic of Indonesia Number SE-2/PK/2021, the adjustment of the use of the budget (refocusing) affects the priority of the use of funds village in 2021, adjustments to the use of the village fund budget include:

- In the context of implementing the Implementation of Micro-Community Activity 
Restrictions (PPKM) in the village, the use of the Village Fund is determined, including:

a. Village Cash Assistance;

b. At least $8 \%$ (eight percent) of the Village Fund received by each village for activities to handle the COVID-19 pandemic which is the village authority, including for COVID-19 safe village actions and COVID-19 safe village task forces.

- The Governor/Regent/Mayor receiving the Village Fund encourages and monitors the implementation of activities to handle the COVID-19 pandemic funded from the Village Fund.

Based on the statement above, the impact of the COVID-19 pandemic and efforts to deal with it through refocusing the budget, especially village funds on a priority scale, are the priority activities in 2021, this also affects efforts to achieve the use of village funds, especially villages without poverty. This indicates that setting the priorities for the use of the Village Fund has an influence on the achievement of the village without poverty in the East Lampung district

\section{B. Suggestion}

Setting Priorities use village funds influences the achievement of the objectives of the program, especially the village without poverty, so to maximize the achievement of the program objectives, setting priorities for the use in addition to taking into account the current situation and conditions, a comprehensive budget also needs to be planned that involves closely related parties during implementation.

\section{ACKNOWLEDGMENT}

Thank you to LPPM (Institute for Research and Community Service) the University of Lampung, which has contributed greatly to this research.

\section{REFERENCES}

[1] S. Budiantoro. Metadata Untuk Penyusunan Rencana Aksi yang Partisipatif. Kementerian PPN dan Bappenas. Jakarta. 2017.

[2] Law No. 6 of 2014 concerning Villages

[3] Government Regulation No. 59 of 2017 concerning the Implementation of the Achievement of the Sustainable Development Goals/SDGs (TPB).

[4] S. Eko, T. I. Khasanah, D. Widuri, H. Suci, N. Handayani, P. Qomariyah, \& B. Kurniawan. Desa Membangun Indonesia. Forum Pengembangan Pembaharuan Desa (FPPD). 2013.

[5] Regulation of the Minister of Villages, Development of Disadvantaged Regions and Transmigration No. 13 of 2020 concerning the Priority for Use of Village Funds in 2021. 